\title{
WOMEN IN THE AUSTRALIAN IT INDUSTRY: WHERE ARE WE NOW?
}

Graeme J. Byrne and Lorraine J. Staehr

School of Engineering and Mathematical Sciences,

La Trobe University, PO Box 199, Bendigo, Australia, 3552

\begin{abstract}
The purpose of this paper is to assess the status of women in the IT industry in 2001 relative to their position in 1996 and in comparison to their status in other industry sectors. To achieve this a special tabulation of 2001 and 1996 Australian census data relating to women's position within the Australian IT industry is analysed. The issues of participation, pay equity and representation at senior management levels are examined. This reveals a fairly negative picture and indicates the need for an intensified effort to rectify the situation. It is shown that women participate in the IT industry at much lower rates than women in many other industries and that they have not achieved pay equity with men. Also, women are not well represented in senior management roles.
\end{abstract}

\section{BACKGROUND}

The ongoing under-representation of women in IT in Australia is well documented (e.g. Newmarch, Taylor-Steele and Cumpston, 2000; von Hellens and Nielson, 2001; APESMA, 2004). This problem is not confined to Australia but is also found in other western countries e.g. the US and the UK (Mai tland, 2001). In Australia this under-representation starts in the education system and persists today despite efforts over the last fifteen years by the government and universities to address the problem. As far back as 1990 the Australian government announced a national objective of $40 \%$ women in non-traditional courses in its discussion paper 'A Fair Chance for All' (DEET, 1990). This resulted in financial support from the Government through the Higher Education Equity Programme (HEEP) for universities to encourage more young women into undergraduate information technology (IT) degrees. Programmes were devised to both encourage the participation and retention of women in these courses. An overview of some of the programmes offered in Australian universities can be found in Craig, Fisher, Scollary and Singh. (1998), and specific details of one such programme at La Trobe University in Staehr, Martin and Byrne (2000).

So, how successful have these programmes been? There is evidence to suggest that although women's participation rate in university degrees may not have reached the targeted $40 \%$ level, there has been an increase in the number of women studying IT. The number of women in the IT industry is not only affected by the number of women gaining IT qualifications from universities, but also from Technical and Further Education (TAFE) Colleges and private providers (e.g. Computer Power Training Institute). In addition, there will be women both already in, and entering the IT industry without formal qualifications in IT. It is only since 1997 that membership of the Australian Computer Society (ACS) at the highest level normally requires formal IT qualifications. Accenture ${ }^{1}$, a high profile IT consulting company, advertises for graduates from Commerce, HR, Business, and Engineering as well as IT. Therefore, there are multiple pathways for women to enter the IT industry in Australia. The number of women with post secondary school qualifications in

1 http:/careers3.accenture.com/Careers/Australia/graduateshome/youquestionsanswered/default.ht $\mathrm{m}$ 
IT (this includes university, TAFE and private providers) increased from 18,986 in 1991 to 46,707 in 2001 (ABS, 2003). However, the percentage of women relative to men actually decreased by $6.3 \%$.

The Australian government has legislated in an attempt to secure equal opportunity for women in the workplace. The Federal Equal Opportunity for Women in the Workplace Agency $^{2}$ was established in 1986 (EOWA). This agency administers the Equal Opportunity for Women in the Workplace Act 1999. The Act requires companies with 100 or more employees to establish a workplace program to remove the barriers to women entering and advancing in the workplace and to report regularly to government. The sanctions for noncompliance are that the company will be named in parliament and the company will be ineligible to tender for government contracts and industry assistance. Companies with particularly good policies are eligible to win awards and have their names publicized in the media, providing incentives for companies to have woman-friendly workplace policies. Currently the requirement is only to have policies in place but there is no compulsion for companies to ensure that the policies are actually achieving benefits for women.

The main purpose of this paper is to report on the status of women in the Australian IT industry. A special tabulation of Australian census data for 1996 and 2001 (ABS, 2002a) is examined, focusing on women's participation and remuneration in the IT industry. Much of the evidence in the literature for the low participation rates of women comes from sample data. Although there will be some inaccuracies $(\sim 1 \%)$, census data is far superior to sample data where errors are often much larger ( 5 to $10 \%$ ). In addition the data used in this paper is disaggregated to the individual occupation level. Although some data is available for 1991, it is not possible to match occupation groups from this census to those in the 1996 and 2001 censuses due to changes in definitions and so 1991 data is not considered. In this paper the best quality data available to date is used due to the revised Australian Standard Classification of Occupations (ASCO) codes. This allows for a much more detailed examination of specific areas within the IT sector so the true extent of the problem can be highlighted. In the following sections the nature of the data is described, data analysis with an integrated discussion is presented, followed by some concluding remarks.

\section{THE NATURE OF THE DATA}

In July 1996, the ASCO scheme was introduced (ABS 1996). Since then, the Australian Bureau of Statistics (ABS) and numerous other agencies (DEST, 2002) have used this standard when classifying employment information. ASCO uses a 6-level coding system that classifies an occupation according to criteria such as; the common and alternative job titles, the skill level of the job and the common tasks carried out. This results in over 1,100 minor occupation groups of which eleven are relevant to IT occupations where significant skill levels are required. These are the minor groups considered in this paper. Occupation data in both the 1996 and 2001 censuses were coded using the ASCO system, which allows detailed examination of the participation of women in IT occupations. The data set obtained for this study covers all of Australia and contains identifiers for 11 occupation groups, 17 industry sectors, and gender for the 1996 and 2001 censuses.

\footnotetext{
${ }^{2}$ http://www.eowa.gov.au/About_EOWA.asp
} 


\section{Occupation descriptions}

The occupation descriptions in Table 1 are based on those provided by the ABS (1996) and DEST (2002). The associated ASCO codes are also displayed. The first digit of these codes indicates the broad occupation group to which these minor groups belong and skill level required decreases as the number increases. A first digit of $\mathbf{1}$ indicates the broad group Managers and Administrators, a $\mathbf{2}$ indicates the broad group Professionals and $\mathbf{3}$ indicates the broad group Associate Professionals. The descriptions of these broad groups based on ASCO definitions (ABS, 1996) are

- Managers and administrators head government, legislative, industrial, commercial, agricultural and other establishments, or departments within these organisations. They determine the policy of the organisation or department, and direct its functioning, usually through other managers, and coordinate economic, social,

- technical, legal and other policies.

- Professionals perform analytical, conceptual and creative tasks through the application of theoretical knowledge and experience in the fields of science, engineering, business and information, health, education, social welfare and the arts.

- Associate professionals perform complex technical and administrative support functions that require an understanding of the underlying theories and methods of a particular field and significant practical skills. Tasks are often performed in support of professionals.

In 2001 within the IT industry there were; 27,198 persons working as managers and administrators of which $6,097(22.4 \%)$ were women, 135,685 persons working as professionals of which $30,339(22.4 \%)$ were women and 29,250 persons working as associate professionals of which 8,972 (30.7\%) were women.

The minor groups chosen for this study, with the exception of Computing Support Technician, all have a minimum entry requirement of a bachelor degree or experience considered equivalent. Electronic engineers were not included as they can have one of three specialisations: biomedical engineer, computer engineer or mechatronic engineer. Computer engineers are included in the ASCO code 2-23113 above. Note also that the data does not include IT research and teaching professionals within the education sector. Where education is mentioned as an industry sector it only includes the IT occupations that would be associated with a computer support centre. 
Table 1: ASCO defined IT occupations and their descriptions (ABS, 1996)

\begin{tabular}{|c|c|c|}
\hline ASCO code & Job Title & Job Description \\
\hline $1-22411$ & $\begin{array}{l}\text { Information } \\
\text { Technology Manager }\end{array}$ & $\begin{array}{l}\text { Plans, administers and reviews the } \\
\text { acquisition, development, maintenance and } \\
\text { use of computer and telecommunications } \\
\text { systems within an organisation. }\end{array}$ \\
\hline $2-22213$ & $\begin{array}{l}\text { Sales Representative } \\
\text { (Information and } \\
\text { Communication } \\
\text { Products) }\end{array}$ & $\begin{array}{l}\text { Represents companies in selling information } \\
\text { and communications equipment, systems } \\
\text { and solutions to businesses. }\end{array}$ \\
\hline $2-23100$ & $\begin{array}{l}\text { Computing } \\
\text { Professionals, } \mathrm{nfd}^{3}\end{array}$ & $\begin{array}{l}\text { Designs and prepares software to meet } \\
\text { specific requirements in all aspects of the } \\
\text { computing environment. Also controls and } \\
\text { audits the operation of computing facilities } \\
\text { within an organisation. (This occupation } \\
\text { group is assigned when no further definition } \\
\text { (nfd) of a more specific nature is recorded } \\
\text { on the census form) }\end{array}$ \\
\hline $2-23111$ & Systems Manager & $\begin{array}{l}\text { Controls the operating effectiveness of } \\
\text { information technology systems, and } \\
\text { arranges system maintenance and } \\
\text { enhancements to meet user requirements. }\end{array}$ \\
\hline $2-23113$ & Systems Designer & $\begin{array}{l}\text { Conducts research into computer and } \\
\text { communications systems, and develops } \\
\text { techniques for their effective application and } \\
\text { use. }\end{array}$ \\
\hline $2-23115$ & Software Designer & $\begin{array}{l}\text { Designs and modifies the operating } \\
\text { environment software which links computer } \\
\text { software and hardware }\end{array}$ \\
\hline $2-23117$ & $\begin{array}{l}\text { Applications and } \\
\text { Analyst Programmer }\end{array}$ & $\begin{array}{l}\text { Writes tests and maintains computer } \\
\text { programs to meet the application needs of } \\
\text { end users of computer systems. }\end{array}$ \\
\hline $2-23119$ & Systems Programmer & $\begin{array}{l}\text { Writes, maintains and updates programs that } \\
\text { control the overall functioning of } \\
\text { computers. }\end{array}$ \\
\hline $2-23121$ & $\begin{array}{l}\text { Computer Systems } \\
\text { Auditor }\end{array}$ & $\begin{array}{l}\text { Designs and monitors control systems, } \\
\text { ensures the integrity and security of data } \\
\text { and reviews the organisation's computing } \\
\text { environment and usage of computer } \\
\text { facilities. }\end{array}$ \\
\hline $2-23179$ & $\begin{array}{l}\text { Computing } \\
\text { Professionals, } \text { nec }^{3}\end{array}$ & $\begin{array}{l}\text { This occupation group covers Computing } \\
\text { Professionals not elsewhere classified and } \\
\text { includes occupations such as Multimedia } \\
\text { Developer, Business (Systems) Analyst and }\end{array}$ \\
\hline
\end{tabular}

${ }^{3}$ Abbreviations; $n f d=$ not further defined and nec $=$ not elsewhere classified, refer to persons who could not be classified into a more definite category. 


\begin{tabular}{|l|l|l|}
\hline & & Web Designer/Developer. \\
\hline $3-29411$ & $\begin{array}{l}\text { Computing Support } \\
\text { Technician }\end{array}$ & $\begin{array}{l}\text { Provides technical advice and support to } \\
\text { users of computer software and hardware. }\end{array}$ \\
\hline
\end{tabular}

\section{DATA ANALYSIS AND DISCUSSION}

According to the 2001 census of population and housing, there were 153,183 persons in Australia with a post-secondary qualification in the IT area. Of this number, $30.1 \%$ were women, which represents a decrease of $6 \%$ on the same figure in 1996. Given that the total number of men and women with IT qualifications increased by almost 70\% between 1996 and 2001, this decline indicates a significant worsening of the trend away from IT education by women. Also, as shown in Table 2, the total number of persons working in IT occupations in 2001 is 192,132, compared with 126,375 persons in 1996 (a 52\% increase). During the same period, women's participation in IT occupations decreased by $2.3 \%$. Thus, no matter how you look at it, the IT industry is failing to attract/retain women and the situation is getting worse. Possible causes have been identified by von Hellens and Nielsen, (2001) and include; misconceptions about the nature of IT work, unfriendly male dominated workplaces and the fact that the nature of IT work makes it difficult to balance work and home responsibilities.

\section{Industry Sectors}

This section presents a detailed examination of women's participation in IT occupations focusing on industry sectors in 2001, and changes during the inter-censual period. Table 2 below shows the numbers of men and women in each of the 17 industry sectors, along with the participation rate of women for the 2001 census. Of the 192,132 persons employed in IT occupations in 2001 , the great majority $(45 \%)$ are employed within the Property and Business Services industry with Finance and Insurance, Manufacturing, Communication Services, Government Administration and Defence, Wholesale Trade, Retail Trade and Education together employing a further $45 \%$ in IT roles.

From a women's participation rate perspective, the best performing industries are Health and Community Services, Personal and Other Services, Finance and Insurance, Agriculture, Forestry and Fishing, and Government Administration and Defence. Interestingly, the industry with the highest number of IT employees (Property and Business Services) has one of the lowest female participation rates at $20.8 \%$. Overall, the participation rate of women in IT occupations is $23.6 \%$, which is less than half the rate for all occupations across all industry sectors (ABS, 2002b). It is probably not surprising that the Health and Community services has by far the highest participation rate as traditionally this industry has employed mainly women. Perhaps this industry sector provides a more supportive environment for women in general, and therefore also for women in IT roles compared with other industry sectors. 
Table 2: Numbers employed in IT occupations classified by industry sector and gender in 2001.

\begin{tabular}{|c|c|c|c|c|c|}
\hline \multirow[b]{2}{*}{ Industry } & \multicolumn{2}{|c|}{$\begin{array}{l}\text { Numbers } \\
\text { Occupations }\end{array}$} & in IT & \multicolumn{2}{|c|}{$\begin{array}{l}\text { Women's } \\
\text { Participation Rate }\end{array}$} \\
\hline & Women & Men & Persons & $\begin{array}{l}\text { IT } \\
\text { occupations }\end{array}$ & $\begin{array}{l}\text { All } \\
\text { occup } \\
\text { ations }\end{array}$ \\
\hline Accomm., Cafes and Restaurants & 136 & 385 & 521 & $26.1 \%$ & $56.1 \%$ \\
\hline Agriculture, Forestry and Fishing & 131 & 315 & 446 & $29.4 \%$ & $30.3 \%$ \\
\hline Communication Services & 2923 & 10573 & 13496 & $21.7 \%$ & $34.0 \%$ \\
\hline Construction & 340 & 1180 & 1520 & $22.4 \%$ & $13.3 \%$ \\
\hline Cultural and Recreational Services & 726 & 2020 & 2746 & $26.4 \%$ & $47.9 \%$ \\
\hline Education & 2353 & 6404 & 8757 & $26.9 \%$ & $68.7 \%$ \\
\hline Electricity, Gas and Water Supply & 517 & 1893 & 2410 & $21.5 \%$ & $19.8 \%$ \\
\hline Finance and Insurance & 5290 & 11637 & 16927 & $31.3 \%$ & $56.3 \%$ \\
\hline Government Admin. \& Defence & 3791 & 9124 & 12915 & $29.4 \%$ & $44.9 \%$ \\
\hline Health and Community Services & 1408 & 2475 & 3883 & $36.3 \%$ & $78.5 \%$ \\
\hline Manufacturing & 2818 & 10888 & 13706 & $20.6 \%$ & $26.6 \%$ \\
\hline Mining & 243 & 805 & 1048 & $23.2 \%$ & $13.6 \%$ \\
\hline Non-Classifiable Economic Units & 213 & 776 & 989 & $21.5 \%$ & $43.3 \%$ \\
\hline Not stated & 117 & 421 & 538 & $21.8 \%$ & $47.4 \%$ \\
\hline Personal and Other Services & 556 & 1205 & 1761 & $31.6 \%$ & $47.2 \%$ \\
\hline Property and Business Services & 17911 & 68086 & 85997 & $20.8 \%$ & $46.3 \%$ \\
\hline Retail Trade & 2268 & 6520 & 8788 & $25.8 \%$ & $52.5 \%$ \\
\hline Transport and Storage & 1035 & 2971 & 4006 & $25.8 \%$ & $25.6 \%$ \\
\hline Wholesale Trade & 2632 & 9046 & 11678 & $22.5 \%$ & $32.3 \%$ \\
\hline All Industries & 45408 & 146724 & 192132 & $23.6 \%$ & $45.2 \%$ \\
\hline
\end{tabular}

\section{Occupation Groups}

This section presents an examination of women's participation in IT focusing on the minor occupation groups and their changes during the inter-censual period.

Figure 1 below shows the percentage breakdown for all persons in the IT occupation groups at the 1996 and 2001 censuses. In both census periods, Applications and Analyst Programmers, Computing Support Technicians, Information Technology Managers, Systems Managers and Software Designers were the major occupation groups. Also, while the total numbers in all occupations except Systems Programmers increased (see Table 3), this growth was not uniform with the percentage share in occupations such as Systems Managers and Computing Support Technicians falling by around $2 \%$ while the percentage share for Software Designers and Information Technology Managers increased by 4.1 and $2.4 \%$ respectively.

Table 3 shows the numbers employed and women's participation rates (WPR) in 1996 and 2001 in each of the minor IT occupation groups defined by ASCO (see Occupation descriptions above). In 2001, women's participation in IT occupations was highest for Computing Support Technicians (30.7\%) with Sales Representatives, Systems Managers and Computer Systems Auditors making up 26-28\% of their respective occupation groups. The 2001 census (ABS, 2002b) puts women's participation in the broad occupation groups (see Occupation descriptions above); Managers and Administrators, Professionals and Associate Professionals at $28 \%, 53 \%$ and $44 \%$ respectively across all industry sectors. As 
mentioned earlier, the participation rates within the IT sector for these broad groups are $22.4 \%, 22.4 \%$ and $30.7 \%$ respectively. Clearly, women managers, professionals and technicians are underrepresented within the IT industry compared with most other industries. This is especially true for Computing Professionals where women's participation is less than one half of the value across all industries. Thus, although many professions such as medicine and law have been successful in attracting women in at least equal numbers to men, the IT profession has a long way to go if equity is to be achieved on this measure.

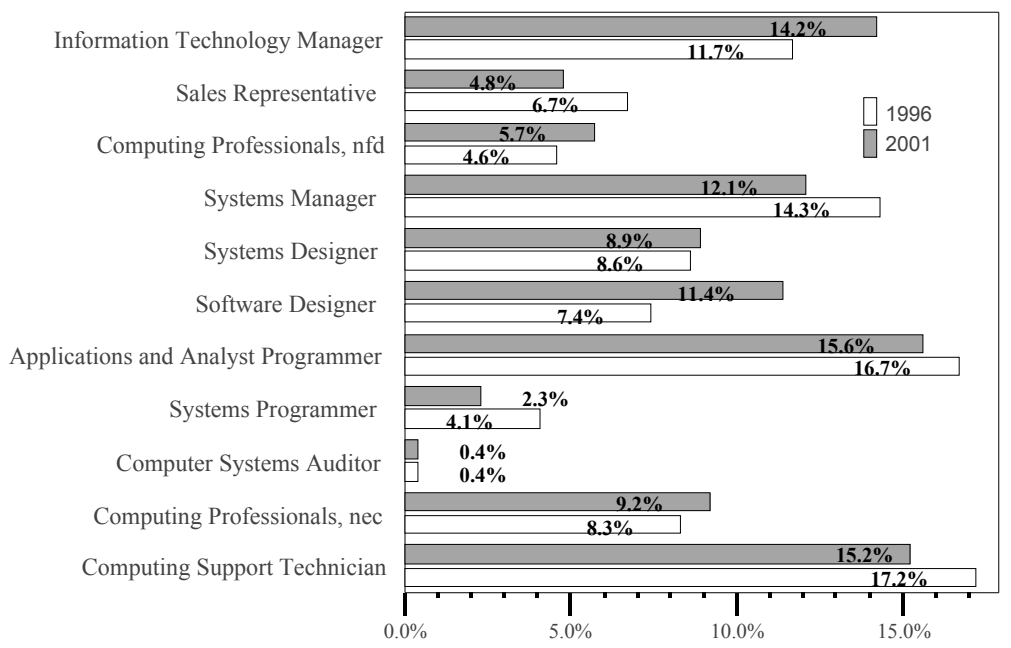

Figure 1: Persons in each IT occupation group as a percentage of all IT occupations 1996 and 2001.

\section{Changes over time}

Also shown in the last column of Table 3 is the inter-censual change in women's participation $(\triangle \mathrm{WPR})$. While there are some encouraging signs with participation increasing by $2.3 \%$ for Computing Professionals nfd, $2.7 \%$ for Software Designers, $2.1 \%$ for Systems Managers and $1.2 \%$ for Information Technology Managers, all other occupation groups exhibited no change or a decline in women's participation between 1996 and 2001. Overall there was a $2.3 \%$ decrease in women's participation in IT occupations in the 5-year period to 2001, the worst situation being for Computing Support Technician where an $11.7 \%$ decline occurred. There is no obvious explanation for this large decline and further research on this issue is required. The overall $2.3 \%$ decrease is worrying, but not surprising, particularly in light of the partially successful efforts by government and the universities to increase the participation and retention rates of women in IT education (Newmarch et al., 2000). 
Table 3: Numbers employed and women's participation by ASCO occupation groups

\begin{tabular}{l|lll|lll|l}
\multicolumn{7}{c}{ in $\mathbf{1 9 9 6}$ and 2001. } \\
\hline & 1996 & & & 2001 & & & \\
\cline { 2 - 8 } & Women & Total & WPR & Women & Total & WPR & $\triangle$ WPR \\
\hline Information Technology Manager & 3142 & 14808 & $21.2 \%$ & 6097 & 27198 & $22.4 \%$ & $1.2 \%$ \\
Sales Representative & 2378 & 8440 & $28.2 \%$ & 2584 & 9191 & $28.1 \%$ & $-0.1 \%$ \\
Computing Professionals, nfd & 1129 & 5850 & $19.3 \%$ & 2369 & 10989 & $21.6 \%$ & $2.3 \%$ \\
Systems Manager & 4686 & 18042 & $26.0 \%$ & 6553 & 23319 & $28.1 \%$ & $2.1 \%$ \\
Systems Designer & 1910 & 10852 & $17.6 \%$ & 2928 & 17195 & $17.0 \%$ & $-0.6 \%$ \\
Software Designer & 1307 & 9346 & $14.0 \%$ & 3681 & 21997 & $16.7 \%$ & $2.7 \%$ \\
Applications and Analyst & 5106 & 21097 & $24.2 \%$ & 6928 & 29944 & $23.1 \%$ & $-1.1 \%$ \\
Programmer & & & & & & & \\
Systems Programmer & 1011 & 5186 & $19.5 \%$ & 861 & 4421 & $19.5 \%$ & $0.0 \%$ \\
Computer Systems Auditor & 165 & 560 & $29.5 \%$ & 223 & 864 & $25.8 \%$ & $-3.7 \%$ \\
Computing Professionals, nec & 2647 & 10451 & $25.3 \%$ & 4212 & 17764 & $23.7 \%$ & $-1.6 \%$ \\
Computing Support Technician & 9252 & 21743 & $42.6 \%$ & 8972 & 29250 & $30.7 \%$ & $-11.9 \%$ \\
\hline Group Total & 32733 & 126375 & $25.9 \%$ & 45408 & 192132 & $23.6 \%$ & $-2.3 \%$ \\
\hline
\end{tabular}

\section{Income Data}

In this section, median incomes of men and women are compared across all minor IT occupation groups. The ABS has determined that the median is the most appropriate measure of typical income for an occupation group (ABS, 2001).

Figure 2 shows that median incomes of women are below that of men in all minor IT occupation groups. Census data (ABS, 2002b) show that far more women work on a part time basis than men and this may explain some of the disparity in income between men and women. However general workforce data from the ACTU (2002) suggest that even after adjusting for part time work effects, a significant disparity remains. Also, the percentage of women engaged in part time work in the IT industry is less than in other occupations (APESMA, 2004) due to the relatively high skill levels required for entry into this profession. Thus it appears that women actually are paid less than men in similar occupations in the IT sector. Given that government legislation in Australia mandates equal pay for equal work regardless of gender the foregoing observation raises serious questions about what is actually happening in the Australian workplace. Kirner and Rayner (1999, p. 26) provide some evidence suggesting that women do not do as well financially when negotiating individual contracts such as Australian Workplace Agreements.

The scatter plot in Figure 3 is an attempt to view the two issues of participation and income equity jointly. It shows the median income for women and men for each minor IT occupation group (indicated by ASCO code) plotted against the corresponding participation rates. If equity in both remuneration and participation rates were to exist, the points for women and men for each occupation group should coalesce along the $50 \%$ line at identical income levels. 


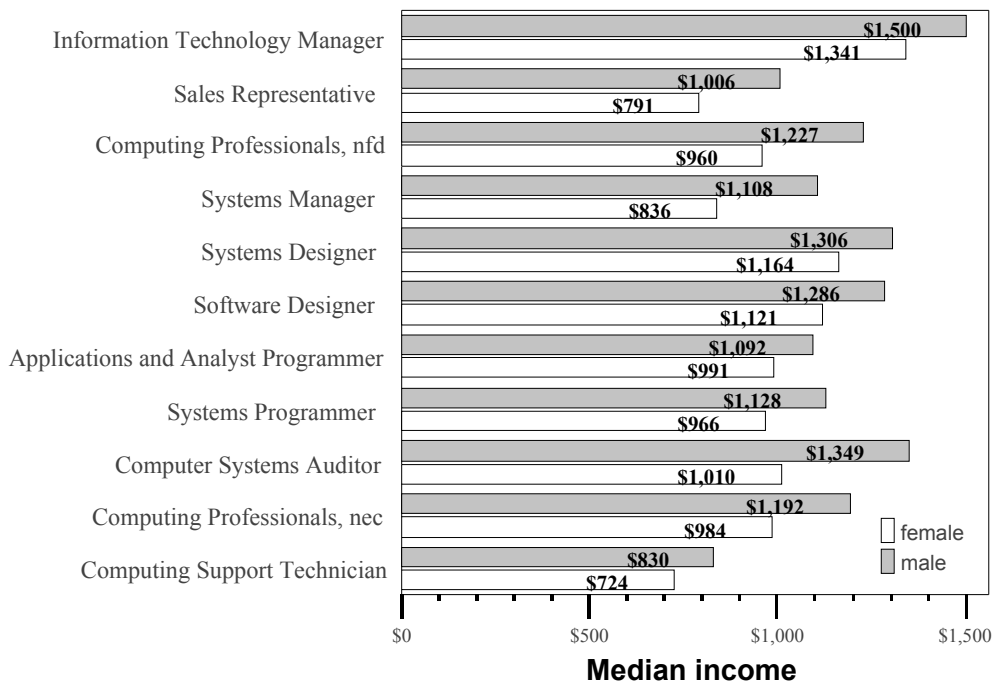

Figure 2: Comparison of men's and women's median incomes in IT occupations 2001

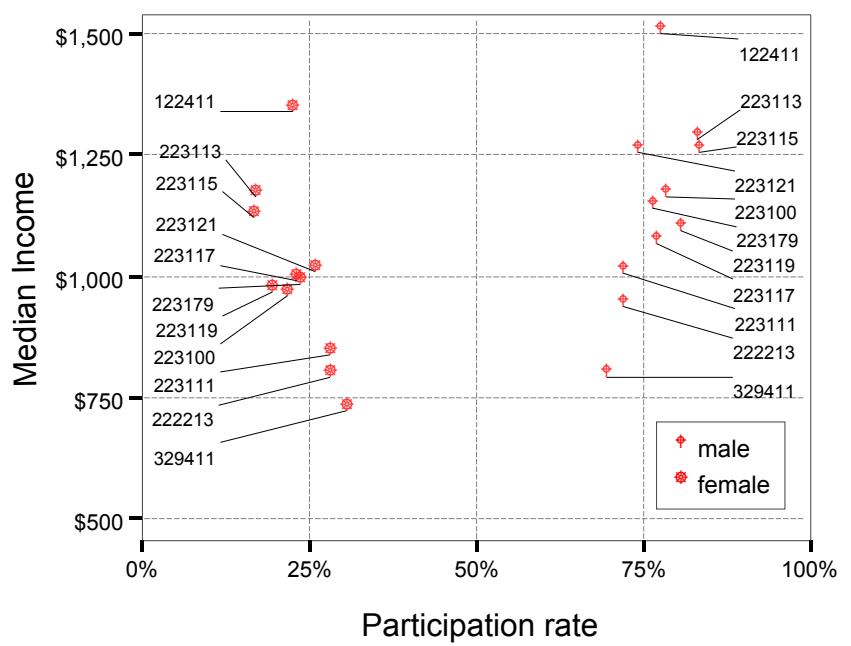

Figure 3: Median income of IT occupations versus participation rate

The substantial horizontal distance between the points along with the generally lower vertical positions of the female points relative to the corresponding male points provides a measure of the extent of gender inequity within the IT industry. This diagram also illustrates that higher participation rates of women are associated with lower incomes while for men the situation is reversed. 


\section{CONCLUSION}

Unfortunately there is little good news. The analysis presented in this paper clearly shows that the position of women within the Australian IT industry did not improve during the 1996 to 2001 period, and in many cases actually worsened. The main results show that the ratio of men to women is about 3 to 1 and women participate in IT occupations at about half the rate found in the general workforce. On an industry basis the Health and Community Service sector appears to provide an environment that supports women in IT occupations but even here the participation rate is far below the figure for other health related occupations. Few women have made inroads into management roles in IT with and those that do appear to earn significantly less than their male counterparts.

Most occupations experienced no change or a decrease in women's participation between 1996 and 2001. Notable exceptions to this were Computing Professionals (nfd), Systems Managers, and Software Designers where gains of between 2\% and 3\% occurred. The occupation group with the highest participation rate is computer support technicians however there was a severe downward trend of nearly 12\% between 1996 and 2001.

Income disparities between men and women occur in IT occupations as in most other occupations. Also, women are concentrated in the lower income occupations of the IT sector. Employment in the IT industry has been falling since 2001 (Houghton, 2003). More recent survey data on women in IT suggests that women have borne the brunt of the financial constraints that accompanied this decline in the sector (APESMA, 2004). It is clear that much work needs to be done if women are to participate and receive financial rewards commensurate with men in the Australian IT industry.

There is some evidence that government has recognised the problems and is moving to address them. Recent initiatives include the establishment of the Victorian Women in ICT Network and the Victorian government's New Realities careers awareness campaign that are designed to attract women to IT careers and provide support for those already in an IT career (see http://www.mmv.vic.gov.au/Home). Also the Australian federal government's Women in ICT Summit Advisory Group established in 2005 (see http://www.dcita.gov.au/ict) is designed to increase the number of women studying and working in IT.

The next Australian census is due in 2006 and it will provide another opportunity to review the situation. If the trend by women away from IT occupations continues then government, universities and industry will need to re-evaluate their strategies to achieve gender equity in IT.

\section{REFERENCES}

Australian Council of Trade Unions [ACTU] (2002) "Pay Equity", URL: http://www.actu.asn.au/public/futurework/payequity.html, Accessed 31 July 2005.

Association of Professional Engineers, Scientists and Managers, Australia [APESMA] (2004) "Women in the Professions - Survey Report 2004", URL http://www.apesma.asn.au/women/survey/women in professions 2004.pdf, Accessed 27 July 2005.

Australian Bureau of Statistics, (1996) “1221.0 -Information Paper: Australian Standard Classification of Occupations", Second Edition, Canberra: ABS.

Australian Bureau of Statistics (2001) "Income Imputation Census Fact Sheet", URL: http://www.abs.gov.au, Accessed 10 Dec 2002. 
Australian Bureau of Statistics (2002a), "2001 Census (Special Tabulation)”, Canberra: ABS.

Australian Bureau of Statistics, (2002b) "CDATA 2001; Your Census at work" (CDROM), Canberra: ABS.

Australian Bureau of Statistics (2003) "2001 Census, Basic Community Profile -Time Series Profile Category no. 2003.0, Table 11", Canberra: ABS.

Craig, A., Fisher, J., Scollary, A. and Singh, M. (1998) "Closing The Gap - Women Education And Information Technology Courses In Australia", Journal of Systems Software, Vol 40, pp 7-15.

Department of Employment, Education and Training [DEET] (1990) "A Fair Chance For All: Higher education that's within everyone's reach", Discussion Paper, Canberra: Australian Government Publishing Service

Department of Education, Science and Training [DEST] (2002) “Job Guide 2002", URL: http://jobguide.dest.gov.au/, Accessed 13 Dec 2002.

Department of Education, Science and Training [DEST] (2001), Higher Education Equity Scheme, URL http://www.dest.gov.au/highered/programmes/heep.htm, Accessed: 10 Dec 2002.

Houghton, J. (2003) “Australian ICT Industries Update” (summary only), Melbourne: Centre for Strategic Economic Studies, URL: http://www.cfses.com/documents/ICT Industries_Update_2003 SUMMARY.PDF, Accessed 31 July 2005.

Kirner, J. and Raynor, M., (1999) The Women's Power Handbook, Ringwood, Australia: Viking.

Maitland, A., (2001) "Where's the New IT Girl?", Financial Times (22 February), p. 9.

Newmarch, E, Taylor-Steele, S and Cumpston, A, (2000), "Women in IT - What are the Barriers?", DETYA, URL: http://www.dest.gov.au/research/pubs/womeninit.htm, Accessed: 25 January 2003.

Staehr, L., Martin, M. and Byrne, G. (2000) Improving the Retention Rates of Women in Computing: An intervention program, Journal of College Student Retention: Research, theory and practice, Vol 2, pp 127-140.

von Hellens, L. and Nielsen, S., (2001) “Australian Women In IT”, Communications of the ACM, Vol 44, pp 46-52.

\section{ACKNOWLEDGEMENTS}

The School of Business and Technology, La Trobe University, Bendigo provided financial support to purchase the census data. 